\title{
Intraoperative assessment of axillary lymph nodes in patients with breast cancer
}

The corresponding author for this Editorial ( $B M J$

2014;349:g6803, doi:10.1136/bmj.g6803) should be J M Dixon (mike.dixon@ed.ac.uk).
Cite this as: BMJ 2014;349:97381

๑ BMJ Publishing Group Ltd 2014 